\title{
Pelatihan Komunikasi Persuasif Dalam Menarik Minat Konsumen Pada Komunitas Wirausaha Perempuan
}

\author{
${ }^{1}$ Dini Safitri, ${ }^{2}$ Nada Arina Romli, ${ }^{3}$ Dania Siregar \\ 1,2,3Universitas Negeri Jakarta, Jl. Rawamangun Muka, Jakarta Timur \\ email: 'dinisafitri@unj.ac.id; ${ }^{2}$ nadaarina@unj.ac.id; ${ }^{3}$ siregardania@yahoo.com
}

\begin{abstract}
The women's entrepreneurial community in Johar Baru Subdistrict, Central Jakarta consists of approximately 30 underprivileged entrepreneurs fostered by Yayasan Senyum Ibu Indonesia (YSII). The problem in the partner environment is the number of community members who do not use promotional media on social media. Even if anyone uses social media, just rely on promotions on whatsapp groups. They do not have enough about communication technology, especially the features on social media and their functions and uses. Therefore, they do not understand marketing and business communication and carry out persuasive product promotions in attracting consumer interest on social media. The purpose of holding this PKM is that the Women Entrepreneurs Community in Johar Baru District, Central Jakarta can activate on social media, so that their business activities are published to citizens. The PKM method is carried out online through the zoom application by providing a balanced time between material and discussion with participants. The result of this activity is that persuasive communication training in attracting consumers can improve UMKM skills in using social media while increasing the number of sales. The participants are also equipped with the importance of educational content on social media to increase consumer interest in buying products.
\end{abstract}

Keywords: Persuasive Communication, Consumer Interests, Women's Entrepreneurial Community

\begin{abstract}
Abstrak. Komunitas perempuan wirausaha di Kecamatan Johar Baru, Jakarta Pusat terdiri dari kurang lebih 30 pengusaha prasejahtera binaan Yayasan Senyum Ibu Indonesia (YSII). Permasalahan di lingkungan mitra adalah banyaknya anggota masyarakat yang tidak menggunakan media promosi di media sosial. Kalaupun ada yang menggunakan media sosial, hanya mengandalkan promosi di grup whatsapp. Mereka tidak memiliki cukup pengetahuan tentang teknologi komunikasi, terutama fitur-fitur di media sosial serta fungsi dan kegunaannya. Oleh karena itu, mereka kurang memahami pemasaran dan komunikasi bisnis serta melakukan promosi produk secara persuasif dalam menarik minat konsumen di media sosial. Tujuan diadakannya PKM ini agar Komunitas Wanita Pengusaha di Kecamatan Johar Baru, Jakarta Pusat dapat aktif di media sosial, sehingga kegiatan usahanya terpublikasi kepada warga. Metode PKM dilakukan secara online melalui aplikasi zoom dengan memberikan waktu yang seimbang antara materi dan diskusi dengan peserta. Hasil dari kegiatan ini adalah pelatihan komunikasi persuasif dalam menarik konsumen dapat meningkatkan keterampilan UMKM dalam menggunakan media sosial sekaligus meningkatkan jumlah penjualan. Para peserta juga dibekali dengan pentingnya konten edukasi di media sosial untuk meningkatkan minat konsumen dalam membeli produk.

Kata Kunci: Komunikasi Persuasif, Minat Konsumen, Komunitas Wirausaha Perempuan
\end{abstract}

\section{Pendahuluan}

Kehadiran media sosial telah dirasakan sebagai sarana yang dapat dimanfaatkan untuk mempermudah urusan manusia. Selain itu, kecenderungan kehidupan masyarakat saat ini tidak dapat jauh dari gadget. Hal itu menjadikan media sosial bagian penting dari penyebaran informasi di Indonesia selama beberapa tahun terakhir (Safitri, Yuliaty, Sary, 2021). Bahkan, kehidupan masyarakat saat ini tidak dapat dipisahkan dari teknologi (Nida, 
2014). Perkembangan teknologi telah membawa perubahan pada kehidupan manusia (Harahap dan Kurniawati, 2018). Kehidupan manusia menjadi lebih dinamis dalam pola interaksi dan komunikasi, seperti penggunaan media sosial untuk kepentingan transaksi dan informasi (Sakhinah dan Arbi, 2019).

Hearne (2014) melakukan penelusuran bahwa Jakarta adalah ibu kota twitter sedunia. Setiap hari 2,4 persen tweet dunia berasal dari Indonesia, artinya 1 tweet dikirim tiap 15 detik. Oleh karena itu, persoalan di Indonesia sering menjadi viral di media sosial dan menjadi perbincangan global di seluruh dunia. Potensi tersebut, sepatutnya dapat dikelola dengan baik dalam pengelolaan isu, terutama yang bertujuan untuk memberdayakan dan menyejahterakan kehidupan bangsa. Sayangnya, belum semua masyarakat Indonesia yang memanfaatkan media sosial sebagai alat komunikasi persuasif untuk menjalankan bisnis wirausaha pada skala kecil dan menengah. Padahal, untuk menggunakan media sosial sebetulnya sangat mudah dan tidak perlu mengeluarkan biaya promosi yang terlalu besar.

Arus digitalisasi dan kehadiran media sosial juga menjadi sarana manusia untuk mencapai efisiensi. Namun, banyak kalangan yang belum dapat memanfaatkan teknologi digital dalam mempermudah usahanya. Salah satunya adalah kelompok wirausaha perempuan yang berada di bawah koordinasi Yayasan Senyum Ibu Indonesia (YSII). Salah satu kendala yang dihadapi mereka adalah belum dapat memanfaatkan media sosial untuk memasarkan usaha yang sudah dijalani. Selain itu, banyak kekhawatiran dan ketakutan yang dihadapi oleh kalangan wirausaha perempuan saat akan memulai usaha dan saat sedang menjalaninya. Untuk mengatasi sejumlah kekhawatiran tersebut, kegiatan Pengabdian Kepada Masyarakat (PKM) ini dilakukan.

TujuandarikegiatanPKMiniadalah untuk melakukan edukasi kepada kurang lebih 30 orang wirausaha perempuan yang ada di bawah naungan YSII di daerah Johar Baru Jakarta Pusat. Dalam kegiatan tersebut, kami memberikan sejumlah materi dan konsultasi yang bertujuan untuk meningkatkan ketersediaan informasi yang lebih luas mengenai Komunikasi Persuasif dalam Menarik Minat Konsumen pada Kalangan Ibu-Ibu Wirausaha di Johar Baru Jakarta Pusat pada masa pandemi Covid-19.

Pandemi Covid-19 saat ini telah memasuki tahun kedua dan belum ada tanda akan segera berlalu. Selama itu, roda perekonomian keluarga banyak yang memburuk. Banyak para ibu yang ikut membantu ekonomi keluarga dengan cara menjadi wirausaha. Dengan keterampilan yang dimiliki, banyak yang mencoba usaha rumahan, tetapi banyak juga yang menyerah dan merasa gamang atas usaha yang dijalani. Usaha rumahan ini bisa dimasukan ke dalam usaha mikro kecil dan menengah (UMKM).

PKM sebelumnya seputar UMKM sudah banyak dilakukan, salah satunya yang dilakukan oleh Hidayat dan tim (2019). Mereka melakukan kegiatan pemberdayaan masyarakat dengan program MELEK (Merek, Label, dan Kemasan). Dalam PKM tersebut, Hidayat memberikan penyuluhan mengenai pentingnya merek, label, dan kemasan produk untuk meningkatkan daya saing UMKM. Dengan menggunakan metode learning dan action, UMKM Kicimpring di Desa Cimata Kabupaten Kuningan Jawa Barat dapat memperbaiki kemasan produk kicimpingnya dan membuat merek dagangnya sendiri.

PKM lainnya adalah PKM yang dilakukan Claudia dan tim yang bertujuan melakukan edukasi kepada anak-anak jalanan yang terpaksa bekerja mencari nafkah karena tidak stabilnya pendapatan akibat pemasukan ekonomi yang lemah. Dalam PKM tersebut, anak jalanan dibekali pendidikan karakter agar tetap bisa menikmati pendidikan dengan 
cara belajar sambil bermain di tengah kesibukan mereka sebagai pekerja anak. Kegiatan PKM tersebut menginspirasi kegiatan PKM ini karena sama-sama ingin memberikan edukasi, tetapi kepada objek yang berbeda. Pada PKM ini, objeknya adalah kelompok wirausaha perempuan yang tergabung di dalam komunitas binaan Yayasan Senyum Ibu Indonesia.

PKM mengenai edukasi lainnya juga dilakukan oleh Darmawan dan tim (2020) yang melakukan edukasi kepada masyarakat mengenai protokol kesehatan yang harus dipatuhi dalam menggunakan transportasi umum di masa pandemi Covid-19 melali live streaming youtube. PKM tersebut menginspirasi kegiatan PKM ini untuk melakukan PKM via media sosial yang ternyata efektif untuk menyosialisasikan aturan-aturan baru di masyarakat selama pandemi Covid-19. Diharapkan, kegiatan PKM ini dapat bermanfaat bagi mitra dalam meningkatkan penjualan selama pandemi Covid-19 melalui komunikasi persuasif.

Penelitian mengenai komunikasi persuasif di sosial media sudah banyak dilakukan. Tujuan melakukan komunikasi persuasif juga beragam, yakni salah satunya penelitian yang dilakukan oleh Hajar dan Anshori (2021). Hajar dan Anshori meneliti komunikasi persuasif yang dilakukan oleh Farah Qoonita, seorang influencer yang juga aktivis dakwah. Farah Qoonita menggunakan media sosial youtube dan podcast dengan pilihan kata yang persuasif, jelas, santun, dan mudah dimengerti. Selain itu, Farah juga melakukan engagement dengan para pengikutnya yang saling menyemangati satu sama lain lewat gambar (desain) atau kata yang diposisikan sebagai teman. Penelitian tersebut memberikan inspirasi untuk PKM ini agar dapat memanfaatkan sosial media untuk kegiatan membantu kelompok wirausaha perempuan yang membutuhkan semangat untuk meningkatkan usahanya melalui aplikasi yang disediakan oleh media sosial dengan membuat desain dan kata-kata yang persuasif dalam menarik minat konsumen.

Keunggulan PKM ini adalah akan melakukan edukasi mengenai komunikasi persuasif untuk menarik minat konsumen, jika dibandingkan PKM sebelumnya. Tim mengajarkan teori dan praktik kepada kelompok wirausaha perempuan di wilayah kecamatan Johar Baru di bawah naungan Yayasan Senyum Ibu Indonesia dan Pokja II Kecamatan Johar Baru Jakarta Pusat. Teori yang diajarkan adalah komunikasi persuasif dan praktik membuat konten persuasif untuk menarik minat konsumen.

\section{Metode Ilmiah}

PKM ini dilakukan melalui aplikasi Zoom. Alasan penggunaan aplikasi Zoom untuk melakukan penyuluhan adalah kondisi yang tidak memungkinkan untuk melakukan penyuluhan secara langsung pada lokasi PKM. Selain itu, alasan lainnya adalah ada penerapan Pembatasan Sosial Berskala Besar (PSBB) dan Pemberlakukan Pembatasan Kegiatan Masyarakat (PPKM) di wilayah DKI Jakarta.

Dengan adanya aplikasi Zoom yang sangat dekat dikalangan ibuibu, hal itu menjadikan PKM ini dapat berjalan dengan baik. Kegiatan PKM ini dilaksanakan dengan bentuk kuliah Zoom kepada anggota grup yang berjumlah 34 orang. Kegiatan dilaksanakan pada tanggal, 25 April 2021, pada pukul 09.00-11.00 WIB. Durasi Kegiatan ini diperpanjang satu jam karena antusias peserta dalam bertanya. Durasi pertanyaan berlangsung seimbang dengan materi karena jawaban yang diberikan dari pembicara sampai kepada teknis melakukan komunikasi persuasif dalam menarik minat konsumen.

Kegiatan PKM ini berlangsung ke dalam dua segmen. Segmen pertama mengenai materi komunikasi persuasif untuk menarik minat konsumen di tengah 
pandemi Covid-19. Segmen kedua adalah segmen praktik dan tanya jawab.

Materi komunikasi persuasif dalam menarik minta konsumen banyak bersinggungan dengan materi mata kuliah copywriting yang kebetulan diampu oleh ketua PKM pada semester ini dan sedang berjalan perkuliahannya.

Pada segmen kedua, kegiatan PKM ini memberikan ruang untuk melakukan praktik dan tanya jawab kepada peserta sekaligus juga memberikan penyuluhan mengenai konten informatif untuk menarik minat konsumen. Tujuan dari segmen praktik dan tanya jawab ini adalah memberikan cara dan informasi kepada kaum ibu mengenai solusi dari masalah yang mereka hadapi dalam menjalankan wirausaha yang tengah mereka jalani agar terampil membuat konten persuasif di media sosial.

\section{Hasil dan Pembahasan}

Hasil PKM ini adalah meningkatnya pengetahuan peserta mengenai komunikasi persuasif dalam meningkatkan minat beli konsumen. Selain itu, perserta juga mempelajari cara membuat konten copywriting di media sosial. Kegiatan ini juga menghadirkan pembicara tamu, yakni seorang wirausaha perempuan yang sukses menjadi reseller buku cerita anak dan telah mendapatkan banyak hadiah dari penerbit atas keberhasilannya dalam menjual buku.

Kegiatan penyuluhan dan konsultasi mengenai komunikasi persuasif untuk menarik minat konsumen di tengah pandemi Covid-19 berhasil meningkatkan pengetahuan peserta untuk berlaku persuasif di media sosial agar menarik minat konsumen. Banyak ibuibu yang awalnya tidak tahu bagaimana cara berjualan di media sosial, seperti Instagram bahkan di dalam WA grup. Padahal, kemampuan tersebut menjadi penting saat ini karena banyak kaum ibu yang merasakan dampak penurunan ekonomi keluarga akibat pandemi. Terlebih lagi daerah Kecamatan Johar Baru yang merupakan daerah padat pemukiman penduduk se-Asia Tengara sehingga masyarakat Johar Baru banyak yang mengalami masalah ekonomi. Para ibu juga harus berpikir kreatif agar urusan dapur bisa tetap terkendali untuk mengatasi masalah ekonomi di dalam keluarga. Oleh karena itu, melalui program PkM ini, kami memberikan sejumlah penyuluhan dan konsultasi yang bertujuan untuk meningkatkan komunikasi persuasif pada kelompok komunitas wirasusaha perempuan di Johar Baru dengan bermitra bersama YSII melalui bentuk kuliah melalui aplikasi zoom pada Minggu, 25 April 2021.

Acara dibuka dengan sambutan yang disampaikan oleh Sekretaris YSII, Ibu Ifa Fauziah dan Sambutan dari Ibu Mariatun sebagai Perwakilan dari Ibu Camat Johar Baru.

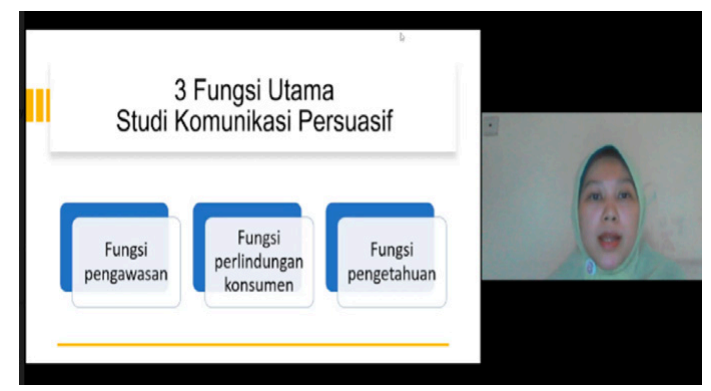

Gambar 1. Presentasi Materi Melalui Zoom

Acara PKM ini mengajarkan peserta untuk melakukan praktik komunikasi persuasif untuk menarik minat konsumen. Di antara materi yang diberikan adalah mengenai tiga fungsi utama studi komunikasi persuasif, yaitu fungsi pengawasan, fungsi perlindungan konsumen, dan fungsi pengetahuan.

Melalui kegiatan PKM komunikasi persuasif untuk menarik minat konsumen ini, tim PKM menemukan beberapa temuan seputar permasalahan komunikasi yang terjadi pada komunitas wirausaha perempuan di tengah pandemi Covid-19. Adapun temuan yang didapat antara lain adalah adanya masalah 
konten pemasaran. Masalah pertama adalah masalah konten pemasaran yang menarik minat pembelian. Ibu-Ibu tidak terbiasanya melakukan copywriting. Padahal, copywriting bisa dilakukan dengan meminta komentar positif dari para pelanggan. Komentar tersebut lalu di-upload di media sosial Instagram. Ibu-Ibu juga belum terbiasa dengan melakukan engagement dengan para followers di media sosial. Mereka kurang interaktif dengan para followers dan belum memiliki akun khusus untuk berjualan.

Masalah kedua adalah pemilihan jenis produk usaha. Selain masalah komunikasi di atas, juga ditemukan banyak kaum ibu yang merasa takut dan menyerah dengan usaha yang tengah dilakukannya. Mereka melihat para pesaing sudah banyak sehingga tidak percaya diri. Padahal, dalam berjualan selain dari kualitas produk yang harus dipertahankan, hubungan komunikasi yang baik dengan para pelangan juga harus dipertahankan. Persaingan adalah hal wajar, tetapi cara memenangkan persaingan adalah sesuatu yang bisa dipelajari dan diusahakan. Begitulah beberapa motivasi yang diberikan oleh tim PKM kepada para peserta kegiatan.

Ketakutan para ibu wirausaha semakain bertambah pada saat pandemi Covid-19 ini. Banyak peserta yang takut jika usahanya tidak laku, tidak laris, dan bahkan merugi. Selain itu, menurut pengakuan ibu-ibu mitra, banyak ketidakberanian untuk melakukan ekspansi usaha. Mereka terkendala waktu dan tenaga. Selain ketakutan tersebut, para ibu wirausaha juga banyak yang merasa tidak bisa mengunakan sosial media dan kurang update informasi mengenai aplikasi atau fitur yang bisa menunjang promosi penjualan. Padahal, aplikasi di sosial media adalah aplikasi yang mudah digunakan dan sangat mudah berbagi informasi kepada orang-orang di dalam jaringan. Yang perlu dilakukan adalah banyak mengikuti acara pelatihan online yang dapat meningkatkan keterampilan dan motivasi berniaga di kalangan pelaku UMKM.

Para pembicara mencoba menawarkan solusi untuk pembuatan konten edukasi terhadap cara pemasaran produk. Dalam membimbing praktik membuat konten edukasi, tim PKM juga menghadirkan pembicara tamu, yaitu Ibu Marisa Puspita Sary seorang entrepreneur sukses dalam bidang marketing buku anak islami. Ibu Marisa membagi kisah suksesnya dalam memasarkan produk buku Islam dan telah banyak mendapatkan bonus atas penjualannya tersebut, di antaranya adalah jalan-jalan ke luar negeri bersama suami. Rahasia kesusksesannya adalah dengan membuat konten edukasi dalam memasarkan paket buku yang dijualnya.

Konten edukasi yang dibuat Marisa antara lain adalah tampil sebagai model dalam membacakan kisah-kisah dalam bukunya, baik pada anak-anaknya dan juga kepada anak-anak PAUD. Ia pun banyak melakukan kegiatan sosial. Dari konten-konten tersebut, banyak akhirnya yang memesan produk buku tersebut. Marisa pintar mengambil kesempatan di acara sosial untuk mempersuasi calon pembeli membeli buku edukasi.

Tim PKM juga mengajarkan cara memilih jenis produk yang akan dijadikan usaha. Tim menyarankan untuk menjual produk yang diminati sendiri oleh penjual. Selain itu, produk tersebut juga sudah terbukti kemanjurannya dan penjual sendiri juga menyukai produk yang dijual. Hal tersebut sesuai dengan materi mengenai etika komunikasi persuasif pada slide terakhir. Peserta tidak diperkenankan menganjurkan sesuatu yang secara pribadi juga tidak tidak dipercaya. Seorang penjual yang tidak menyukai produk yang dijualnya akan kesulitan bila akan mempersuasi orang lain.

Solusi yang ditawarkan tim PKM agar peserta dapat melakukan penjualan yang sukses adalah dapat 
memilih produk yang dijual mewakili dari diri penjual. Jadi, penjual juga sudah merasakan manfaat dari produk yang dijualnya. Penjual harus dan perlu membangun kredibilitasnya sebagai brand ambassador dari produk yang dijualnya. Produk yang dijual mewakili representasi dirinya (Yuliaty, Sari, Safitri, 2013).

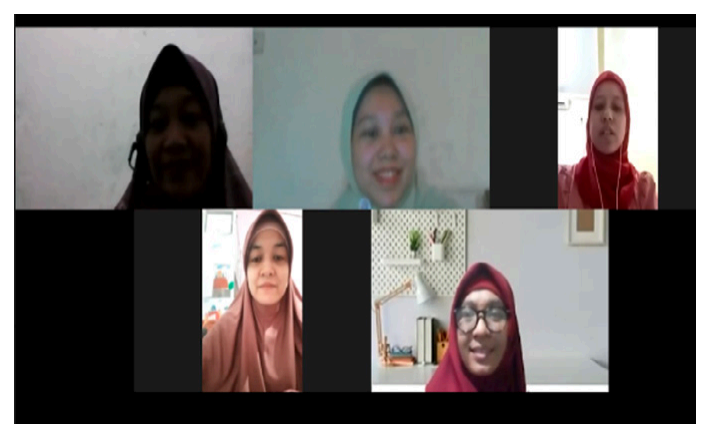

Gambar 2. Sesi Tanya Jawab antara Pemateri dan Peserta disertai Moderator

Solusi lainnya yang ditawarkan adalah pebisnis pemula dapat memilih produk yang tahan lama untuk dipasarkan. Hal tersebut diterapkan untuk menghindari kerugian pada masa awal-awal menjual. Namun, bila terpaksa menjual produk yang tidak tahan lama, maka strategi yang dapat dilakukan adalah membuat konten pre-order. Dengan konten pre-order, penjual hanya akan membuat produk sebatas pesanan saja. Cara ini dilakukan agar tidak ada produk yang tersisa dan terbuang karena dibuat sesuai dengan pesanan dan transaksi pembayaran yang sudah dibayarkan sebelumnya. Penjual juga perlu berhati-hati dalam melakukan transaksi, pesanan hanya dibuat dengan syarat dan ketentuan yang berlaku.

Bagi wirausaha perempuan yang merasa takut dan menyerah dengan usaha yang tengah dilakukannya, solusi yang ditawarkan adalah mencoba melakukan bisnis baru yang tidak memiliki risiko kerugian yang tinggi. Saran bisnis yang ditawarkan adalah menjadi reseller atau distributor alih-alih menjadi produsen.

Bagi peserta yang berniat menjadi produsen harus siap dengan banyak waktu, tenaga, pikiran yang akan tersita untuk membuat bisnisnya berjalan. Produsen wirausaha perempuan tersebut memang harus sudah berniat untuk merintis usaha sebagai produsen. Sebelumnya, ia sudah menghitung modal usaha dengan membuat rencana usaha yang sudah matang.

Peserta juga tidak semuanya disarankan menjadi produsen atau reseller, tetapi juga diarahkan untuk menjadi investor. Bagi wirausaha perempuan yang memiliki banyak uang, bisa juga beralih menjadi investor untuk membantu usaha dari wirausaha perempuan lainnya yang dinilai bisa mendapatkan profit besar bila dimanajemeni dengan profesional. Sebagai seorang investor, mereka harus memiliki kejelian bahwa jenis usaha ini akan bisa dikembangkan dengan menyediakan modal sekian untuk mendapatkan keuntungan berlipat yang sudah diperhitungkan.

Arahan lain untuk para peserta adalah arahan untuk melakukan kolaborasi. Untuk wirausaha perempuan yang takut melakukan usaha pada saat pandemi Covid-19 ini, karena takut usahanya tidak laku, tidak laris, dan bahkan merugi, mereka ditawarkan untuk melakukan kolaborasi bisnis. Caranya dengan bekerja sama dan bergabung dengan sesama pegiat komunitas untuk saling like, membuat testimoni positif, dan membuat jejaring pada sosial media masing-masing yang digunakan untuk penjualan. Saat ini berjamur komunitas online untuk UMKM, pengusaha muda, dan lainnya. Komunitas tersebut rajin membuat acara online untuk update pengetahuan, keterampilan, sekaligus membangun ekosistem bisnis mereka dengan cara kolaborasi.

Arahan lainnya adalah untuk yang sudah memiliki usaha dan sudah terbiasa menggunakan media sosial untuk berjualan agar dapat meng-update media sosial menjadi akun bisnis untuk memudahkan kinerja penjualan. Di 
dalam akun bisnis terdapat fitur yang lebih baik dan lengkap untuk mengukur kinerja penjualan dan promosi yang sudah dilakukan. Terdapat fitur analisis yang menjadi dasar untuk pembuatan rencana dan inovasi bisnis UMKM.

Adapun arahan untuk ibu-ibu mitra yang tidak berani melakukan ekspansi usaha karena mereka terkendala waktu dan tenaga, solusi yang bisa dilakukan adalah dapat berkolaborasi dengan jasa layanan bisnis. Contohnya, bagi ibu-ibu yang bergerak di bidang kuliner, para Ibu dapat berkolaborasi dengan cloud kitchen yang menyediakan juru masak, pengataran, bahkan mengelola sosial media untuk kegiatan marketing.

Masalah lainnya adalah para ibu wirausaha banyak yang merasa tidak bisa mengunakan sosial media dan kurang update informasi mengenai aplikasi atau fitur yang bisa menunjang promosi penjualan. Solusi yang ditawarkan adalah dibentuk kelompok mentoring wirausaha yang dapat menjadi tempat bertanya mengenai fungsi dari fiturfitur sosial media yang dapat menunjang peningkatan penjualan. Saat acara hendak ditutup, permintaan untuk kelas mentoring wirausaha menjadi pekerjaan rumah para pembicara dan mitra yang akan terus ditindaklanjuti.

\section{Kesimpulan dan Saran}

Kesimpulan dan saran berjudul Pelatihan Komunikasi Persuasif dalam menarik minat konsumen pada kalangan wirausaha perempuan di Johar Baru Jakarta Pusat telah menghasilkan peningkatan edukasi kepada mitra untuk membuat konten edukasi dalam menarik minat konsumen untuk membeli. Banyak contoh dan pengalaman dari para narasumber yang membuktikan konten edukasi lebih efektif untuk meningkatkan minat konsumen melakukan pembelian.

Acara ini juga didukung oleh Pokja II Kecamatan Johar Baru yang membidangi program pendidikan dan keterampilan serta pengembangan kehidupan berkoperasi. Selain itu, acara ini juga dihadiri Ibu Lurah Tanah Tinggi dan Kampung Rawa, Ibu Yayah Syamsiah.

Saran untuk kegiatan PKM mendatang, pada tahun kedua dan ketiga adalah apabila pandemi covid-19 berlalu, akan diadakan kegiatan PKM komunikasi persuasif untuk menarik minat konsumen pascapandemik Covid-19.

\section{DAFTAR PUSTAKA}

Claudia, C., Prabawati, H., Malihah, M., Novrezi, M., Sahara, S., Safitri, D. (2019). Pelatihan Pendidikan Karakter Pada Anak Pekerja Di Yayasan SWARA Peduli Indonesia Jakarta. Ethos: Jurnal Penelitian dan Pengabdian Kepada Masyarakat (Sains \& Teknologi) Vol 8 (1), 1-8

Darmawan, B., Dwiyanti, M., Fatkhan, A., Safitri, D. (2020). Edukasi Penggunaan Transportasi Publik DKI Jakarta Di masa Pandemi Covid-19. Abdimas Unwahas 6 (1), 13-17

Hajar, S. A., dan Anshori, M.S., (2021). Strategi Komunikasi Persuasi Farah Qoonita dalam menyampaikan Dakwah Melalui New Media. Aksiologi: Jurnal Pendidikan dan Ilmu Sosial 1 (2), 62-66

Harahap, H. S., dan Kurniawati, D.I. (2018). WhatsApp sebagai Media Strategi Komunikasi Ustadzah dalam Menyampaikan Dakwah (Studi Deskriptif Kualitatif Komunitas Belajar Islam Seru). DiMCC Conference Proceeding 1, 131-150

Hearne, A. (2014). Peran Media sosial di Pemilu Indonesia 2014. Ditulis 1 April 2014, http://www.radioaustralia.net. au/indonesian/2014-03-31/ peran-sosial-media-di- pemiluindonesia-2014/1285446 
Hidayat, A. S., Kartono, K., Mardiyani, M., Lisara, I. (2019). Meningkatkan Daya Saing UMKM Kicimpring Melalui Program "Melek UMKM". Ethos: Jurnal Penelitian dan Pengabdian Kepada Masyarakat (Sains \& Teknologi) Vol 8 (1), 2532

Nida, F. L. K. (2014). Persuasi Dalam Media Komunikasi Massa. At Tabsyir, Jurnal Komunikasi Penyiaran Islan 2 (2), 77-95

Safitri, D., Yuliaty, K.Y.S., Sary, M.P. (2021). Socialization Effectiveness of Five Key Safety by BPOM to Foster Individual Understanding During the Covid-19 Pandemic. 2nd International Confence on Universal Wellbeing, 44-49

Sakhinah, S dan Arbi, A. (2019). Persuasive Strategic

Communication: Tabligh in Komunitas Anak Muda Berhijrah or Hijrah Youth Community. Dakwah: Jurnal Kajian Dakwah dan Kemasyarakatan 23 (1), 22-39

Yuliaty, K.Y.S, Sari, W.P., Safitri, D. (2013). Pengantar Komunikasi Bisnis. Jakarta: Ulinnuha Press 